\title{
HUBUNGAN FAKTOR PERSONAL (EMPATI) DENGAN PERILAKU ALTRUISTIK PADA ANGGOTA KORPS SUKARELA PALANG MERAH INDONESIA (KSR-PMI) DI INSTITUSI X
}

\section{Correlation of Personal Factor (Empathy) with Altruistic Behaviour in Members of Volunteer Corps-Indonesian Red Cross(KSR-PMI) on Institution X}

\author{
Nur Ainiyah, Muhammad Khafid, Sulistyorini \\ Fakultas Keperawatan dan Kebidanan, UNUSA \\ Email : ainiyahannuriunusa.ac.id, khafid@unusa.ac.id, sulistyorini@unusa.ac.id
}

\begin{abstract}
ABSTRAK
Kegawat daruratan merupakan suatu kondisi ketika seseorang dalam keadaan mengancam jiwa atau bahkan akan dapat mengakibatkan kecacatan permanen apabila tidak ditolong dengan segera. Peningkatan mutu pelayanan gawat darurat membutuhkan kerjasama secara terpadu dan terintregasi antara PMI dengan sektor lain terutama KSR-PMI dari beberapa institusi perguruan tinggi. akan tetapiselama 3 bualn terakhir sebagian besar anggota KSR di institusi $\mathrm{X}$ sebagian besar tidak mau ikut serta dalam kegiatan pertolongan pertama kegawatdaruratan. Tujuan Penelitian ini adalah untuk mengetahui hubungan faktor personal (empati) dengan perilaku altruitik pada anggota KSR PMI di Institusi X. Metode dalam penelitian ini adalah analitik korelatif dengan pendekatan cross sectional. Populasi penelitian ini adalah seluruh anggota KSR-PMI X sejulah 75 anggota. Sampel dalam penelitian ini adalah penelitian berjumlah 63 anggota, dengan menggunakan consecutive sampling. Pengumpulan data dilakukan pada bulan Juni 2019 menggunakan kuisioner yang telah melalui uji validitas dan realibilitas. Analisa data yang digunakan adalah rank spearmen. Hasil penelitian menunjukkan uji hipotesa rank spearman yaitu koefisien korelasi sebesar $0,492(\mathrm{p}=0,001 ; \mathrm{p}<0.05)$, menunjukkan arah yang positif, dan kekuatan hubungannya adalah sedang, sehingga $\mathrm{H} 1$ diterima ada hubungan antara faktor personal (empati ) dengan perilaku altruistic pada anggota KSR PMI X. Oleh karena itu diharapkan semua anggota KSRPMI dapat mengembangakan rasa empatinya, meningktakan komitmennya dalam berperan serta dalam kegiatan kegawatdaruratan
\end{abstract}

Kata Kunci: faktor personal,empati, perilaku altrusitik, korps relawan

\begin{abstract}
An emergency is a condition when someone is in a life-threatening condition or even can cause permanent disability if not helped immediately. Improving the quality of emergency services requires integrated and integrated cooperation between PMI and other sectors, especially KSR-PMI from several tertiary institutions. but for the last 3 months, the majority of KSR members in Institution X mostly did not want to take part in emergency first aid activities. The purpose of this study was to determine the relationship of personal factors (empathy) with altruistic behavior among KSR PMI members in Institution X. The method in this study was correlative analytics with the cross-sectional approach. The population of this research is all members of KSR-PMI X as many as 75 members. The sample in this study was a study of 63 members, using consecutive sampling. Data collection using questionnaires that have passed the test of validity and reliability. Analysis of the data used was rank spearmen. The results showed rank spearman hypothesis test that the correlation coefficient of $0.492(p=0.001 ; p<0.05)$, showed a positive direction, and the strength of the relationship was moderate, while H1 was accepted there was a relationship between personal factors (empathy) and altruistic behavior. Therefore, it is expected that all KSRPMI members can develop their empathy, increase their commitment to participating in emergency activities.
\end{abstract}

Keywords: personal factor, empathy, altruistics behaviour

PENDAHULUAN 
Kegawatdaruratan merupakan suatu kondisi ketika seseorang dalam keadaan mengancam jiwa atau bahkan akan dapat mengakibatkan kecacatan permanen apabila tidak ditolong dengan segera. Keadaan kegawat daruratan yang sering terjadi di masyarakat antara lain kecelakaaan di jalan raya, cedera ketika mengikuti pertandingan, henti nafas atau henti jantung secara tiba-tiba, tidak sadarkan diri, lain sebagainya. Oleh karena itu perlu adanya peningkatan mutu pelayanan gawat darurat dan membutuhkan kerjasama secara terpadu dan terintregasi antara Palang Merah Indonesia (PMI dengan sektor lain seperti Satuan Polisi Pamong Praja (Satpol PP), Badan Penelitain dan Pengembangan Masyarakat Litbangmas (Balitbangamas) serta KSR-PMI dari beberapa institusi perguruan tinggi. Kepedulian anggota Korps Sukarela (KSR) di institusi $X$ terhadap kegiatan kegawatdaruratan mulai menurun. Hal ini diketahui pada sebagian besar anggota KSR-PMI tidak mau ikut serta dalam kegiatan pertolongan pertama kegawatdaruratan dalam tiap minggu dan event. Fenomena yang terjadi adalah ketika tiap komandan KSR-PMI diminta untuk menyetorkan anggotanya untuk ikut jaga di kegiatan tersebut, anggota KSR tersebut sebagian besar tidak mau ikut serta dalam kegiatan pertolongan pertama kegawatdaruratan.

Keanggotaan KSR PMI di X pada tiap tahunnya diikuti kurang lebih 25 orang, sehingga dalam waktu 3 tahun terdapat 75 orang yang masih tergabung dalam keanggotaan. Dalam setiap kegiatan KSRI PMI $\mathrm{X}$ diberikan kesempatan oleh PMI untuk mengikutsertakan anggotanya 3-7 orang. Dari 75 anggota kurang lebih hanya sekitar 15 mahasiswa yang mau ikut serta (perilaku altruistik) secara aktif dalam setiap kegiatan pertolongan pertama pada setiap kegiatan PMI.

Altruisme merupakan paham kepedulian yang tidak mementingkan kepentingan diri sendiri melainkan untuk kebaikan orang lain (Baron \& Byrne, 2008). Altruistik juga berarti perilaku membantu orang lain tanpa pamrih (Oda Ryo, 2013). Perilaku altruistik ini dipengaruhi oleh rasa empati, harga diri, pengetahuan, kecerdasan emosional. Jika altruisme ini kurang dimiliki oleh relawan dalam menolong kondisi gawat darurat maka korban akan terlambat tertangani sehingga berakibat tingginya angka kematian dan kecacatan

Dalam meningkatkan nilai perilaku altrustik pada relawan perlu adanya reinforcement dalam menumbuhkan kembali rasa empati dan meningkatkan pengetahuan serta ketrampilan dari relawan dalam memberikan pertolongan pada korban kegawatdaruratan

\section{METODE}

Metode dalam penelitian ini adalah analitik korelatif dengan pendekatan cross sectional, yang bertujuan untuk mengetahui hubungan antara dua variabel yaitu faktor personal (empati ) dan perilaku altruistik.

Populasi penelitian ini adalah seluruh anggota KSR-PMI X, sejumlah 75 anggota Sampel dalam penelitian ini adalah penelitian berjumlah 63 anggota, dengan menggunkan consecutive sampling. Penelitian ini dilakukan pada Juni 2019.

Pengumpulan data menggunakan kuisioner dengan beberapa item pernyataan yang meliputi semua aspek dari variabel faktor personal (empati) dan perilaku altruistik. Skala dari kedua variabel tersebut disusun dengan permodelan skala likert. Langkah-langkah yang dilakukan membakukan kuesioner penelitian dengan melakukan pengujian validitas dan realibilitas terlebih dahulu. Uji validitas dalam penelitian ini adalah validitas konstrak dengan validitas faktor personal (empati) sebesar 0,306-0,765, sedangkan perilaku altruistik mempunyai validitas sebesar $0,332-0,769$. Uji reliabilitas dalam penelitian ini adalah uji konsistensi internal dengn menggunakan Alpha Cronbach, faktor personal (empati) sebesar mempunyai reliabilitas sebesar 0,725. sedangkan perilaku altrusitik sebesar 0,878. Teknik analisis data yang digunakan oleh peneliti adalah teknik uji korelasi Rank Spearman dengan bantuan program IBM SPSS 21.0 for windows. Berikut ini adalah tabulasi 
silang dan hasil analisis dalam penelitian ini.

Tabel 1 Tabulasi Silang dan hasil Analisis Rank Spearmen Faktor Personal (Empati) dan Perilaku Altruistik pada KSR PMI di Institusi X

\begin{tabular}{|c|c|c|c|c|c|c|c|c|c|}
\hline \multirow[t]{3}{*}{ No } & \multirow{3}{*}{$\begin{array}{l}\text { Faktor } \\
\text { Personal } \\
\text { (empati) }\end{array}$} & \multicolumn{6}{|c|}{ Perilaku Altruistik } & \multicolumn{2}{|c|}{ Total } \\
\hline & & \multicolumn{2}{|c|}{ Tinggi } & \multicolumn{2}{|c|}{ Sedang } & \multicolumn{2}{|c|}{ Rendah } & & \\
\hline & & $\mathbf{F}$ & $\%$ & f & $\%$ & f & $\%$ & f & $\%$ \\
\hline 1 & Tinggi & 8 & 12.7 & 10 & 15.8 & $\overline{\mathbf{0}}$ & $\mathbf{0}$ & 18 & 28,5 \\
\hline 2 & Sedang & 9 & 14.2 & 29 & 46 & $\mathbf{0}$ & $\mathbf{0}$ & 38 & 60,2 \\
\hline 3 & Rendah & $\mathbf{0}$ & $\mathbf{0}$ & 1 & 1.59 & 6 & 9.52 & 7 & 11,11 \\
\hline \multicolumn{2}{|c|}{ Total } & 17 & 26.9 & 40 & 63.4 & 6 & 9.52 & 63 & 100 \\
\hline
\end{tabular}

\section{HASIL DAN PEMBAHASAN HASIL}

Berdasarkan uji hipotesa rank spearman correlation, diketahui bahwa terdapat hubungan antara faktor personal (empati ) dengan perilaku altruistic pada anggota KSR PMI di Institusi X. Koefesien korelasi sebesar 0,492 termasuk dalam kategori sedang dengan kriteria nilai $(0,60-0,799)$. Hasil yang diperoleh ngkat empati pada anggota KSR PMI X diketahui pada kategori tinggi $28,57 \%$ (18 anggota) dan kategori sedang 60,32\% (38 anggota ) sedangkan pada kategori rendah 11.11 (7).

Empati adalah kemampuan untuk memahami perasaan orang lain dan merespon dengan respon yang sesuai. Menurut Gunarsa (2014) empati dianggap sebagai salah satu cara yang efektif dalam usaha mengenali, memahami, dan mengevaluasi orang lain, sehingga ketika mengetahui ada situasi kegawatdaruratan maka individu yang mempunyai rasa empati yang tinggi akan mengambil keputusan untuk segera ikut serta dalam menolong korban tersebut.

Demikian pula menurut Solekah (2018) dan Rieffe dan Camodeca (2016) bahwa faktor yang mempengaruhi empati adalah pola asuh, sosialisasi, usia, mood dan feeling dan jenis kelamin. dari perhitungan menggunakan teknik RankSpearmen correlation menunjukkan arah yang positif, dan kekuatan hubungannya adalah sedang.

\section{PEMBAHASAN}

Berdasarkan Tabel 1 diketahui bahwa bahwa pada kategorisasi ti

Dalam penelitian ini diketahui bahwa sebagian besar mahasiswa berusia 21-24 tahun yaitu sebesar 52 anggota $(82,53 \%)$, yang termasuk fase remaja Penelitian ini juga menunjukkan bahwa responden yang memiliki empati yang tinggi dan sedang mencapai $88,79 \%$, dan sebagian besarnya adalah berjenis kelamin perempuan, Biasanya sebagian besar perempuan mempunyai hati yang lebih peka ketika ada kejadian yang membutuhkan pertolongan. Hal serupa ditemukan pula dalam penelitian Wardhani (2018) yang menunjukkan bahwa perempuan mempunyai empati lebih tinggi daripada laki laki. Rasa empati yang tinggi pada responden kemungkinan juga disebabkan karena anggota KSR PMI sering berinteraksi dengan korban kegawatdaruratan, Hal ini sesuai dengan Stern \& Cassidy (2016). Bahwa sesorang yang sering berinteraksi dan ber mak arasa Empati 
pada dirinya akan perilaku sosial antara individu dapat meningkat.

Peneliti juga berpendapat bahwa Empati yang tinggi ini disebakan karena altruisme adalah tingkah laku menolong orang lain (Yi $\mathrm{Hu}$, dkk, 2016) begitu pula menurut Myers (2012) altruisme didefinisikan sebagai hasrat untuk menolong orang lain tanpa mementingkan atau memikirkan kepentingan sendiri. Responden dalam penelitian ini memiliki karakteristik yang berbeda yaitu ketika menjadi anggota KSR-PMI $X$ ada yang karena terpaksa, ada pula anggota KSR-PMI yang juga ikut organisasi yang lain, tetapi ada pula yang memang berniat dan siap memberikan waktu, tenaga, pikiran maupun materinya untuk membantu dalam setiap kegiatan kegawatdaruratan .Seseorang yang masuk dalam keanggotaaan korps sukarela menunjukan bahwa individu tersebut sudah berkeinginan serta siap untuk menjadi sukarelawan kesehatan dalam kejadian papaun terutama kejadian kegawatdaruratan, sebab relawan ini tidak mendapat imbalan dari hasil kinerjanya, meskipun terkadang ada honor jaga event. Hal ini ditunjukkan dengan statistic deskriptif bahwa yang menunjukan bahwa terdapat $26.99 \%$ (17 anggota) yang memiliki tingkat altruisme tinggi dan $63.49 \%$ ( 40 anggota) dengan altruisme sedang, sedangkan 9.52\% (6 anggota) yang memiliki tingkat altruisme yang rendah. Terbukti bahwa berdasarkan penelitian ini jumlah anggota yang memiliki tingkat altruisme rendah dalam event kegawatdaruratan lebih sedikit dibandingkan dengan anggota yang memiliki tingkat altruisme tinggi dan sedang. Tingkat altruisme rendah altruism yang rendah ini kemungkinan disebabkan karena adanya desakan waktu atau adanya kesibukan yang tinggi pada masingmasning individu. Hal ini sesuai dengan Sarwono dan Meinarno dalam Nusantara (2016). Menurut peneliti altruisme yang tinggi bisa disebabkan karena tingkat religiusitas yang tinggi hal ini ditunjukkan bahwa 100 persen anggota adalah beragama islam. Hal ini sesuai dengan Gatot (2015) bahwa orang yang beragama cenderung mau untuk menolong orang lain diabndingkan orang yang tidak beragama

Berdasarkan pada uji hipotesis RankSpearmen correlation, diketahui bahwa terdapat hubungan antara faktor personal (empati ) dengan perilaku altruistic pada anggota KSR PMI X. Koefesien korelasi Rho sebesar 0,492 termasuk dalam kategori sedang dengan kriteria nilai $(0,60-0,799)$. Hasil yang diperoleh dari perhitungan menggunakan teknik Rank-Spearmen correlation menunjukkan arah yang positif, dan kekuatan hubungannya adalah sedang.

Hal ini sesuai dengan peelitian Fatimah (2015) yang menunjukkan bahwa altruisme erat kaitannya dengan empati. Ketika individu mempunyai rasa empati yang besar maka akan cenderung mau untuk menolong. Hasil korelasi dalam penelitian ini termasuk dalam kategori sedang dan bersifat positif.

Hubungan faktor personal (empati) dan altruisme menunjukan kecenderungan perilaku altruitik, yaitu peduli dan ikut serta dalam menolong orang lain seperti bersedia untuk ikut merasakan penderitaan orang lain, mampu dan bersedia menolong dengan tulus, memberi atau menolong tanpa syarat tertentu, mengikuti event kegawatdaruratan apapun eventnya, serta dapat memahami bagaimana kondisi orang lain.

\section{KESIMPULAN}

Hasil penelitian menunjukkan ada hubungan factor personal (Empati) dengan perilaku altruistic pada anggota KSR-PMI di Institusi $\mathrm{X}$, dengan koefesien korelasi pada kategori sedang dengan nilai positif. Oleh karena itu diharapkan semua anggota KSRPMI dapat mengembangakan rasa empatinya, meningkatakan komitmennya dalam berperan serta dalam kgiatan kegawatdaruratan 


\section{DAFTAR PUSTAKA}

Baron, R. A \& Byrne, D. (2008). Psikologi Sosial. Alih Bahasa: Ratna Djuwita. Jakarta: Erlangga.

Fatimah, Siti (2015). Hubungan Antara Empati Dengan Perilaku Altruisme Pada Mahasiswa Psikologi Universitas Muhammadiyah Surakarta.http://eprints.ums.ac.id/377 98/1/02.\%20NASKAH\%20PUBLIK ASI.pdf. Diakses tanggal 25 Juli 2019

Gatot, Irwan. Hubungan Tingkat religiusitas dengan Perilaku altruitik pada santri. http://eprints.walisongo.ac.id/5248/1/ 104411067.pdf. Diakses tanggal 26 Juli 2019

Gunarsa, S. D \& Gunarsa, Yulia. S. D (2014). Psikologi Perkembangan Anak dan Remaja. Jakarta: PT.BPK: Gunung Mulia.

Myers, D, G (2012). Psikologi sosial.Edisi sepuluh. Jakarta: Salemba Humanika.

Nusantara, Bobby Ardhian. 2018. Hubungan Tingkat Altruisme dengan Konseling Mahasiswa. http //lib.unnes.ac.id/28666/1/130141108 1.pdf. diakses tanggal 26 Juli 2019

Oda, Ryo, WataruMachii, Shinpei Takagi, Yuta Kato, Mia Takeda, Toko Kiyonari, Yasayuki Fukawa. 2013. Personality and Individual Differences (Personality and altruism in daily life). Elseiver. Volume
56, January 2014, Diakses tanggal 20 januari 2019.

Stern, Jessica A \&Jude Cassidy. 2016. Empathy from infancy to adolescence: An attachment perspective on the development of individual differences. https://www.sciencedirect.com/science/a rticle/pii/S0273229717300849. Diakses tanggal 26 juli 2019

Solekhah, Anna Mudarisatus., Atikah, Tera Pertiwi., Istiqomah, Mufidah. 2018. Faktor-Faktor Yang Mempengaruhi Sikap Empati Terhadap Perilaku Prososial Pada Anak Sekolah Dasar. Disampaikan dalam Prosiding Seminar Nasional "Penguatan Pendidikan Karakter Pada Siswa Dalam Menghadapi Tantangan Global" Kudus, 11 April 2018.http://pgsd.umk.ac.id/files/prosidin g/2018/13_Anna_M_S_dkk_86-90.pdf. Diakses tanggal 26 Juli 2018

Wardhani, Hapsari. Empati Ditinjau Dari Pola Asuh Orang Tua Dan Jenis Kelamin. http://eprints.ums.ac.id/60187/1/NASKA H\%20PUBLIKASI.pdf diakses tanggal 26 juli 2019.

Yi Hu,Tian, Jingyu-Li, Huiyuan Jia and Xiaofei Xie. 2016. Helping Others, Warming Yourself: Altruistic behaviours increase warmth Feelings of the Ambient Environment. Frontiers in Psicology. September 2016. Vol 7, Article 1349. Hal 1-2. 